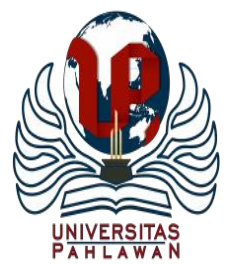

Edukatif : Jurnal Ilmu Pendidikan Volume 3 Nomor 5 Tahun 2021 Halm 3145 - 3153

EDUKATIF: JURNAL ILMU PENDIDIKAN

Research \& Learning in Education

https://edukatif.org/index.php/edukatif/index

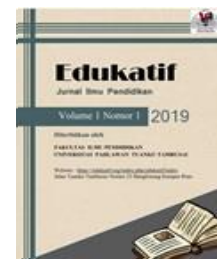

\title{
Analisis Framing Berita Perundungan pada Media Online Detik.Com dan Tribunnews.Com sebagai Bahan Ajar Teks Berita di SMP
}

\author{
Neng Tika Harnia ${ }^{1 凶}$, Ferina Meliasanti $^{2}$, Hendra Setiawan ${ }^{3}$ \\ Universitas Singaperbangsa Karawang, Indonesia ${ }^{1,2,3}$ \\ E-mail : $1710631080113 @$ student.unsika.ac.id $^{1}$, ferina.meliasanti@ fkip.unsika.ac.id ${ }^{2}$, \\ hendra.setiawan@fkip.unsika.ac.id ${ }^{3}$
}

\begin{abstract}
Abstrak
Rendahnya kemampuan masyarakat dalam memahami isi teks berita, sehingga penelitian ini bertujuan untuk mengetahui bagaimana suatu framing berita bekerja dalam membentuk suatu pemberitaan. Metode yang digunakan pada penelitian ini adalah metode kualitatif deskriptif. Hasil penelitian menunjukkan bahwa terdapat perbedaan dalam melakukan framing oleh media Detik.com dan Tribunnews.com terutama pada unsur sintaksis dan tematik. Pada aspek sintaksis media Detik.com menuliskan pemberitaan dengan menggunakan ketenangan dimana dalam setiap judul pemberitaannya ditulis dengan menggunakan kata-kata perdamaian. Sedangkan pada Tribunnews.com dalam menuliskan judulnya bersifat menggeretak dengan penggunaan kata "viral" dan melibatkan Polisi pada judul membuat masyarakat menjadi penasaran terhadap pemberitaannya. Unsur tematik pada media Detik.com terdapat penggunaan kata ganti nama untuk menyebutkan narasumber dan terdapat koherensi penjelas dan sebab akibat dalam penulisan pemberitaannya. Sedangkan pada Tribunnews.com tidak menggunakan kata ganti dan hanya terdapat koherensi penjelas saja. Penggunaan Bahan ajar berupa handout disusun dengan disesuaikan antara materi ajar teks berita dengan KD silabus kelas VIII SMP yang berlaku sehingga dapat meningkatkan keefektifan pembelajaran teks berita bagi siswa dan memudahkannya dalam memahami materi secara keseluruhan dengan lebih efektif.
\end{abstract}

Kata Kunci: analisis framing, berita perundungan, bahan ajar.

\section{Abstract}

The low ability of the public to understand the content of news texts, so this study aims to find out how framing news works in shaping a news story. The method used in this research is a descriptive qualitative method. The results showed that there were differences in framing by media Detik.com and Tribunnews.com, especially in syntactic and thematic elements. In the syntactic aspect of the media, Detik.com writes news using calm wherein each news title is written using the words peace. Meanwhile, Tribunnews.com in writing the title is jarring with the use of the word "viral" and involving the police in the title makes the public curious about the news. The thematic elements in media Detik.com include the use of pronouns to name sources and there is explanatory coherence and cause and effect in the writing of the news. Meanwhile, Tribunnews.com does not use pronouns and there is only explanatory coherence. The use of teaching materials in the form of handouts is arranged according to the news text teaching material and the applicable KD syllabus for class VIII SMP so that it can increase the effectiveness of news text learning for students and make it easier for them to understand the material as a whole more effectively.

Keywords: framing analysis, bullying news, teching materials.

Copyright (c) 2021 Neng Tika Harnia, Ferina Meliasanti, Hendra Setiawan

$\triangle$ Corresponding author:

Email : 1710631080113@student.unsika.ac.id

DOI : https://doi.org/10.31004/edukatif.v3i5.1240

ISSN 2656-8063 (Media Cetak) ISSN 2656-8071 (Media Online)

Edukatif : Jurnal Ilmu Pendidikan Vol 3 No 5 Tahun 2021 p-ISSN 2656-8063 e-ISSN 2656-8071 
3146 Analisis Framing Berita Perundungan pada Media Online Detik.Com dan Tribunnews.Com sebagai Bahan Ajar Teks Berita di SMP - Neng Tika Harnia, Ferina Meliasanti, Hendra Setiawan

DOI: https://doi.org/10.31004/edukatif.v3i5.1240

\section{PENDAHULUAN}

Pandemi covid-19 masih menjadi masalah di dunia tidak hanya di Indonesia. Masalah tersebut tidak hanya berdampak dalam aspek kesehatan melainkan dari beberapa aspek seperti sosial, ekonomi, hingga pendidikan. Berbagai macam kegiatan harus dibatasi dan tidak berkerumun. Selaras dengan pernyataan menurut (Afiana, 2021: 2363) mengatakan adanya pandemi covid-19 pemerintah membuat beberapa kebijakan berupaya menghentikan penyebaran virus ini diantaranya, membuat kebijakan Pembatasan Sosial Berskala Besar (PSBB). Akan tetapi, kebijakan tersebut dirasa kurang berkerja dengan maksimal sehingga kini pemerintah membuat kebijakan baru yakni Pemberlakuan Pembatasan Kegiatan Masyarakat (PPKM).

Namun, ditengah adanya permasalahan mengenai pandemi covid. Terdapat sebuah permasalahan yang tidak kalah besar yakni mengenai kasus perundungan atau yang biasa di kenal dengan istilah "bullying". Di Indonesia kasus bullying semakin hari semakin marak terjadi, walaupun ditengah situasi pandemi kasus ini tidak pernah padam dan seolah selalu saja ada cela bagi seseorang untuk melakukan perundungan. Perundungan merupakan suatu tindakan yang didasari atas penyalah gunaan kekuasaan yang dimiliki oleh pelaku perundungan guna menyakiti seseorang atau sekelompok orang yang tidak memiliki kekuasaan dengan melakukan tindakan fisik, verbal maupun psikologis korban agar merasa tertekan dan trauma sehingga tidak ada perlawanan (Sejiwa, 2008).

Kasus perundungan memiliki dampak yang memiliki resiko besar baik untuk masalah kesehatan fisik maupun mental seseorang. Adapun masalah yang akan diderita oleh korban perundungan antara lain, timbulnya penyakit mental seperti kegelisahan, bahkan depresi, keluhan kesehatan fisik, merasa diawasi dan tidak aman saat berada di lingkungan sosial, serta menurunnya semangat dalam menjalankan aktivitas. Kasus perundungan yang terjadi di Indonesia kini tidak mengenal batasan usia dan gender dimana berbagai kalangan dan tingkat usia kerap melakukan kasus perundungan sesuka hati mereka. Yang lebih parah kasus perundungan juga kerap terjadi di dunia pendidikan. Menurut (safitri, 2019: 245) menyatakan bahwa sekolah rentan sekali memunculkan olok-olokan mengenai kesukuan, latar belakang, bahkan agama di antara siswa, panggilan mbak, butet, cici, masuk dalam kehidupan sehari-hari dan dipraktikan secara dengan penuh sense of humor serta toleransi.

Maka dari itu, diperlukan sebuah kebijakan dan edukasi mengenai kasus perundungan dan bahayanya tindakan perundungan bagi korban maupun pelaku perundungan sekalipun. Untuk itu banyak sekali media di Indonesia yang memberitakan mengenai kasus perundungan guna memberikan informasi dan pernyataan bagi masyarakat yang mengalami kasus perundungan untuk tidak segan melaporkan kepada orang yang dianggap kompeten selain itu adanya pemberitaan pada media massa tersebut guna memberikan edukasi pada masyarakat terkait kasus perundungan agar kasus serupa tidak terulang kembali dimasa yang akan datang.

Media massa yaitu sebuah media untuk massa yang memberikan informasi dengan istilah pers. Media massa memiliki ideologi dan visi misi tertetu yang dapat mempengaruhi kebijakan redaksional media tersebut (Januar, 2016: 202). Media massa adalah suatu sarana bagi masyarakat. Dalam bidang jurnalistik, media massa dapat dikatakan dengan istilah pers yaitu menyiarkan suatu berita atau informasi. Menurut Undang Undang pokok pers pasal 1 ayat (1) bahwa pers merupakan lembaga sosial serta alat komunikasi massa yang melakukan aktivitas semacam mencari, mendapatkan, memiliki, menyimpan, mengelola, serta mengantarkan berupa tulisan, suara, foto, grafik, maupun yang lainnya pada media elektronik atau cetak (Widarmanto, 2017: 9-10).

Sebuah media masa tidak dapat berdiri sendiri. Oleh karena itu, diperlukan sebuah penopang guna membuat media tersebut dapat berdiri dengan adanya seseorang yang bertugas melakukan pengelolahan informasi untuk disampaikan pada masyarakat yang disebut dengan istilah gatekeeper (Chandra, 2017: 4). Media massa memiliki suatu cara yang berbeda-beda dalam mengkonstruksi realitas berita guna membawa masyarakat agar sepaham dengan pandangannya dalam melihat suatu realitas, maka dari itu, banyak 
3147 Analisis Framing Berita Perundungan pada Media Online Detik.Com dan Tribunnews.Com sebagai Bahan Ajar Teks Berita di SMP - Neng Tika Harnia, Ferina Meliasanti, Hendra Setiawan

DOI: https://doi.org/10.31004/edukatif.v3i5.1240

masyarakat yang memiliki pemahaman yang beragam terkait kasus serupa. Hal tersebut disebabkan karena darimana masyarakat medapatkan informasi tersebut.

Media online merupakan suatu sarana komunikasi yang cara penggunaannya dengan memanfaatkan koneksi internet. Media online memiliki sebuah karakteristik yang khas yaitu terletak pada bagaimana cara penggunaannya, dengan menggunakan perangkat komputer maupun smartphone yang dilengkapi dengan jaringan internet. Media online mempunyai perkembangan yang menarik perhatian, hampir setengah penduduk di dunia menggunakan media internet sebagai alat guna mengakses berbagai informasi (Suryawati, 2011: 4649). Pemberitaan yang dapat dimasuki dimana dan kapan saja dengan terhubung pada suatu koneksi internet (Fadilah, 2020: 4).

Media online memiliki kelebihan dibandingkan dengan media lainnya. Hal tersebut selaras dengan pernyataan Nilamsari (2016: 108) yang mengatakan bahwa media online tidak memiliki keterbatasan dimensi ruang dan waktu sehingga dapat menjadi daya tariknya sebagai sebuah media informasi. Adapun media online yang menjadi subjek penelitian ialah Detik.com dan Tribunnews.com.

Detik.com merupakan media informasi yang ada di Indonesia berdiri pada tanggal 9 Juli 1998. Kini menjadi media online nomor 1 di Indonesia menurut situs Alexa.com yang terdapat fitur detiktravel, detikhealth dan yang lannya. Menurt Kurnia (2021: 30) mengatakan bahwa Detik.com adalah media infomasi pelopor untuk media berbasis online.

Tribunnews.com adalah salah satu media informasi di Indonesia berbasis online. Teribunnews.com dinaungi oleh PT. Tribun Digital Online, divisi Koran Daerah Kompas Gramedia (Group of Regional Newspaper) yang berdiri pada tanggal 22 Maret 2010. Walaupun dapat dikatakan sebagai situs yang masih muda namun Tribunnews.com dapat menempati posisi tiga besar setalah media Detik.com dan Kompas.com.

Menurut Romli dalam (Hikmat, 2018) berita adalah sebuah laporan mengenai suatu peristiwa yang cara melaporkannya dengan menggunakan media massa. Dapat disimpulkan kalau bila ada suatu kejadian yang tidak diterbitkan kedalam media massa, sehingga tidak dikenal orang banyak hingga tidak dapat disebut dengan berita. Berita adalah laporan mengenai sebuah peristiwa yang terjadi di suatu tempat baik mengenai seorang tokoh ataupun yang lainnya yang dapat mempengaruhi pembaca untuk bersikap lebih baik lagi (Suryawati, 2011: 69). Maka dari itu, dapat disimpulkan bahwa berita adalah sebuah laporan mengenai suatu peristiwa penting dan menarik yang terjadi di suatu tempat kemudian disampaikan dengan cepat oleh wartawan untuk diliput sebuah media agar dapat diketahui oleh masyarakat secara luas. Terdapat perbedaan dalam menuliskan kriteria nilai yang diperlukan guna dijadikan sebagai penentu fakta yang akan dianglat, kriteria tersebut disebut dengan proximity atau kedekatan (Putri, 2012: 20).

Termasuk berita pada media Detik.com dan Tribunnews.com yang tampak menarik untuk dianalisis. Penelitian ini mengenai kasus perundungan yang di pada media Detik.com dan Tribunnews.com. Melalui hal tersebut, dapat diketahui bagaimana sebuah media dalam mengkonstruksi berita yang akan sampaikan pada masyarakat. Kemudian hal apa yang akan ditonjolkan dan bahkan dihilangkan. Namun, untuk melihat itu semua diperlukan sebuah analisis framing.

Framing berita merupakan suatu cara media mengemas sebuah berita dengan menonjolkan satu pesan yang ingin disampaikan agar masyarakat tertuju pada satu pesan yang ditonjolkan oleh media tersebut. (Eriyanto, 2018) mengatakan framing berkaitan dengan struktur dan proses kognitif, bagaimana seseorang mengolah sejumlah informasi dan ditunjukkan dalam skema tertentu. Framing berkaitan dengan penyusunan skema dalam mengolah sejumlah informasi yang akan disampaikan kepada masyarakat. Framing berfungsi untuk membuat sebuah berita menjadi memiliki kepentingan untuk diketahu masyarakat (Kurniawan, 2019: 19).

Analisis framing Zhongdang Pan dan Gerald M. Kociski ini digunakan dalam penelitian ini karena model tersebut merupakan model analisis framing yang sangat detail dalam melihat sebuah pembingkaian suatu berita. Model ini tentu berbeda dengan model analisis lainnya. Karena sudah menjadi kelebihan 
3148 Analisis Framing Berita Perundungan pada Media Online Detik.Com dan Tribunnews.Com sebagai Bahan Ajar Teks Berita di SMP - Neng Tika Harnia, Ferina Meliasanti, Hendra Setiawan

DOI: https://doi.org/10.31004/edukatif.v3i5.1240

tersendiri pada model analisis Zhongdang Pan dan Gerald M. Kociski ini yang dapat melihat suatu pembingkaian berita secara detail dan hampir semua aspek pada berita yang tidak dimiliki oleh model analisis framing lainnya. (Eriyanto, 2018) mengatakan Pan dan Kociski mengartikan bahwa analisis framing merupakan sebuah proses membuat pesan yang lebih menonjol, menempatkan informasi lebih daripada yang lain sehingga khalayak lebih tertuju pada pesan tersebut. Adapun empat struktur yang terkait untuk menganalisis suatu berita, yaitu struktur sintaksis, skrip, tematik dan retoris.

Dalam penelitian mengenai berita perundungan pada Detik.com dan Tribunnews.com. Dari keduanya terdapat bebagai perbedaan dan perrsamaan dalam menuliskan berita dilihat dari unsur sintaksis, skrip, tematik, dan retoris. Hal tersebut menjadi sebuah kewajaran apabila media memberikan informasi yang berbeda dalam pengemasannya sebab setiap media memiliki cara tersendiri dalam menyampaikan sebuah berita pada masyarakat. Perbedaan dalam framing berita bisa terjadi karena bagaimana sudut pandang wartawan dalam mengemas berita

Maka dari itu dengan melakukan penelitian ini pembaca adapat memahami dengan baik mengenai isi pemberitaan dengan jelas dan benar sesuai dengan realitas yang terjadi. Penggunaan framing dapat bermanfaat tidak hanya bagi masyarakat secara keseluruhan. Namun, teori framing ini dapat bermanfaat bagi siswa tingkat SMP yang keterikatan dengan pembelajaran Bahasa Inonesia yang tertera di silabus pembeljaran pada KI dan KD 3.1 dan 4.1 mengenai materi teks berita dengan mempelajari mengenai apa itu teks berita dan bagaimana cara mengidentifikasi unsur-unsur teks berita berupa pengertian teks berita, unsur-unsur berita $(5 \mathrm{~W}+1 \mathrm{H})$. Hal tersebut selaras dengan aspek yang dianalisis menggunakan teori framing yang terdapat struktur skrip menganalisis mengenai unsur-unsur teks berita berupa $(5 \mathrm{~W}+1 \mathrm{H})$. Sehingga analisis framing ini dapat dimanfaatkan sebagai bahan ajar berupa handout bagi siswa tingkat SMP pada pembelajaran Bahasa Indonesia materi teks berita. Peneliti memilih handout sebagai bahan ajar, karena handout dapat memunculkan mengenai poin-poin utama dan dapat menjadi pelengkap dalam metri pembelajaran pada buku teks meupun materi yang diberikan secara lisan. Sehingga hasil penelitian ini bermanfaat bagi siswa SMP dalam menganalisis dan menulis teks berita

Adapun penelitian sebelumnya membahas mengenai analisis framing berita perndungan sebagai bahan ajar teks berita adalah Resti Rismayanti (2020), yang judul "Framing Berita Perundungan dalam Pemberitaan Media Elektronik sebagai Bahan Ajar Teks Berita untuk Siswa SMP (Analisis Framing Model Robert N. Entman)". Hasil penelitian ini menunjukkan teks berita perundungan dari media elektronik (online) dapat digunakan sebagai bahan pertimbangan bahan ajar di sekolah yang relevan dengan persebaran invormasi saat ini di kalangan siswa SMP.

Penelitian lainnya ialah Lailatul Maghfiroh (2020) dengan judul "Analisis Framing Pemberitaan Kontroversi Film The Santri di Media Online Voa-Islam.Com dan Tribunnews.Com". Hasil penelitian ini terdapat perbedaan pembingkaian antara VOA-Islam.com yang lebih menyudutkan trailer film the santri dengan masalah etika serta syariat Islam. Agama menjadi pokok pembahasan makna santri. sedangkan Tribunnews.com bersifat klarivikasi dan berit yang ditampilkan kedua media tersebut berhasil membuat opini sesuai dan ideologi masing-masing.

Sedangkan peneliti memilih menganalisis framing berita perundungan pada media online Detik.com dan Tribunnews.com sebagai bahan ajar teks dengan tujuan untuk memberikan referensi bahan ajar terhadap pembelajaran Bahasa Indonesia materi teks berita pada kelas VIII guna memudahkan siswa dalam memahami materi pembelajaran yang di susun dengan menarik dan sederhana guna. Selain itu bertujuan untuk mengetahui bagaimana suatu framing berita bekerja dalam membentuk suatu pemberitaan guna memberikan pemahaman mengenai bagaimana cara memahami isi suatu pemberitaan pada suatu media yang dikemas sesuai ideologinya sehingga masyarakat tidak termakan oleh berita hoak. 
3149 Analisis Framing Berita Perundungan pada Media Online Detik.Com dan Tribunnews.Com sebagai Bahan Ajar Teks Berita di SMP - Neng Tika Harnia, Ferina Meliasanti, Hendra Setiawan

DOI: https://doi.org/10.31004/edukatif.v3i5.1240

\section{METODE PENELITIAN}

Metode yang digunakan pada penelitian ini adalah metode kualitatif deskriptif. (Sugiyono, 2017) mengemukakan metode penelitian kualitatif merupakan metode penelitian yang didasari oleh filsafat postpositivisme, guna meneliti suatu kondisi obyek secara alamiah, di mana peneliti adalah sebagai instrumen kunci, teknik pengumpulan data dilakukan secara triangulasi (gabungan), analisis data bersifat induktif/kualitatif, dan hasil penelitian kualitatif lebih menekankan makna dari pada generalisasi.

Penelitian mengenai framing berita yang didasari oleh teori framing Zhongdang Pan dan Gerald M. Kociski yang mengatakan bahwa framing berita adalah sebuah proses membuat pesan yang lebih menonjol, menempatkan informasi lebih daripada yang lain sehingga khalayak lebih tertuju pada pesan tersebut, (Eriyanto, 2018) Peneliti menggunakan model ini karena terdapat 4 elemen pembentuk suatu berita yang saling berkaitan dalam sebuah kontruksi pemberitaan di antaranya yaitu sintaksis, skrip, tematik, dan retoris.

Teknik pengumpulan data diakukan dengan 1)mengumpulkan informasi yang berkaitan dengan permasalahan penelitian di Detik.com dan Tribunnews.com, 2) menyimak penggunaan kosa kata yang digunakan pada media Detik.com dan Tribunnews.com. Kemudian teknik analisis data dilakukan dengan cara yaitu 1) mengelompokkan berita mengenai kasus perundungan pada Detik.com dan Tribunnews.com, 2) membaca dan menandai gagasan penting, 3) menganalisis dengan menggunakan framing Zhongdang Pan dan Gerald M. Kosicki, 4)mendeskripsikan hasil analisis, 5) penarikan kesimpulan kedalam bentuk paparan hasil analisis untuk dijadikan sebagai bahan ajar teks berita. Berikut ini data berita kasus perundungan pada media online Detik.com dan Tribunnews.com yang akan diteliti.

Tabel 1

Data Berita yang akan Diteliti

\begin{tabular}{|c|c|c|c|c|}
\hline \multirow[t]{2}{*}{ No } & \multicolumn{2}{|c|}{ Detik.com } & \multicolumn{2}{|c|}{ Tribunnews.com } \\
\hline & aktu Terbit & Judul Berita & aktu Terbit & Judul Berita \\
\hline 1 & $\begin{array}{l}\text { Kamis, } 22 \\
\text { April } 2021\end{array}$ & $\begin{array}{l}\text { Dalih bercanda, } \\
\text { pria Bogor } \\
\text { pelaku banting } \\
\text { bocah ke sawah }\end{array}$ & $\begin{array}{c}\text { Jumat, } 23 \\
\text { April } 2021\end{array}$ & $\begin{array}{l}\text { Viral video bocah } \\
\text { dibully berkali-kali } \\
\text { dilempar ke sawah, } \\
\text { pelaku diburu polisi }\end{array}$ \\
\hline 2 & $\begin{array}{c}\text { Rabu, 04 } \\
\text { Agustus } 2021\end{array}$ & $\begin{array}{l}\text { Kasus siswa SMP } \\
\text { dipukuli gegara } \\
\text { tek beri rokok di } \\
\text { Bengkuli } \\
\text { berakhir damai }\end{array}$ & $\begin{array}{c}\text { Rabu, 04 } \\
\text { Agustus } \\
2021\end{array}$ & $\begin{array}{l}\text { Video bullying siswa } \\
\text { SMP Bengkulu viral di } \\
\text { medsos, Polisi turun } \\
\text { tangan }\end{array}$ \\
\hline
\end{tabular}

\section{HASIL DAN PEMBAHASAN PENELITIAN}

Analisis penelitian ini guna mengetahui bagaimana suatu framing dalam pemberitaan pada media Detik.com dan Tribunnews.com bekerja dan bagaimana implementasinya sebagai bahan ajar teks berita bagi siswa.

\section{Analisis pemberitaan kasus perundungan pada Detik.com.}

Judul berita: Dalih bercanda, pria Bogor pelaku banting bocah ke sawah.

\section{Struktur sintaksis}

Penggunaan lead berita memaparkan mengenai pengakuan pelaku yang membanting bocah ke sawah mengaku hanya bercanda. Dalam penulisan berita ini terdapat empat kutipan sumber yang dijadikan sebagai landasan penulisan teks berita. sumber tersebut diperoleh dari Kaporles Bogor AKBP Harun, Kalpolsek Klapanunggal AKP Fadli Iman, Ajat Suderajat, dan seseorang didalam video. Namun, pada teks berita ini wartawan tidak menuliskan opininya mengenai kasus tersebut. Pada bagian penutup meyatakan terdapat video 
3150 Analisis Framing Berita Perundungan pada Media Online Detik.Com dan Tribunnews.Com sebagai Bahan Ajar Teks Berita di SMP - Neng Tika Harnia, Ferina Meliasanti, Hendra Setiawan

DOI: https://doi.org/10.31004/edukatif.v3i5.1240

beredar yang menunjukan seseorang anak laki-laki yang sama duduk diatas jok dengan menggendong kebadan pembonceng.

\section{Struktur skrip}

Penggunaan struktur skrip pada berita ini dapat dikatakan lengkap dengan memenuhi unsur $5 \mathrm{~W}+1 \mathrm{H}$ dengan baik.

\section{Struktur tematik}

Pemberitaan mengenai kasus tersebut memiliki 17 paragraf yang ditulis dengan baik sehingga berkesinambungan antar kalimat satu dengan yang lainnya. Selain itu dalam penggunaan unsur tematik wartawan menggunakan kata ganti nama untuk menyebutkan Kaporles Bogor AKBP Harun. Dan terdapat koherensi penjelas yang ditandai dengan kata dan" pada paragraf ke 2, 5, 7, 8, 9, dan 15.

\section{Struktur retoris}

Struktur retoris pada berita ini terdapat kata "bullying" atau perundungan yang berarti suatu perbuatan atau sikap intimidasi terhadap korban yang tidak memiliki kekuasaan.

Judul berita: Kasus siswa SMP dipukuli gegara tek beri rokok di Bengkuli berakhir damai

\section{Struktur sintaksis}

Penggunaan lead pada berita ini berisi pernyataan Polisi mengenai perdamaian antara kudua belah pihak pelaku dan korban pemukulan yang disebabkan karena pelaku meminta rokok pada korban yang tidak merokok. Pada teks berita ini terdapat satu kutipan yang disampaikan oleh narasumber yaitu Kabid Humas Polda Bengkulu Kombes Sudarno. Namun, secara keseluruhan dalam penulisan berita ini jurnalis tidak memasukan opininya terkait kasus perundungan siswa SMP di Bengkulu. Penutup pada berita ini berisi pernyataan mengenai pelaku yang menepuk pundak dan memandangnya setelah di beri uang.

\section{Struktur skrip}

Penggunaan struktur skrip pada berita mengenai kasus penganiayaan terhadap perawat ini telah memenuhi semua unsur pembangun berita yakni unsur $5 \mathrm{~W}+1 \mathrm{H}$.

\section{Struktur tematik}

Dalam pemberitaan tersebut terdapat 16 paragraf yang ditulis dengan baik sehingga berkesinambungan antar kalimat satu dengan yang lainnya. Selain itu dalam penggunaan unsur tematik wartawan menggunakan kata ganti nama untuk menyebutkan Humas Polda Bengkulu Kombes Sudarno. Selanjutnya terdapat dua jenis koherensi penjelas dan koherensi sebab akibat. koherensi penjelas yang ditandai dengan kata "dan" pada paragraph ke 2, 5, 6, 7, 9, 13, dan 15. Dan koherensi sebab akibat ditandai kata "karena" pada paragraf ke 4, 9 , 11 , dan 12.

\section{Struktur retoris}

Terdapat penggunaan kata "bully" pada judul berita yang berarti perbuatan mengganggu dan mengusik secara terus menerus. Kemudian terdapat kata "viral" pada penulisan berita yang berarti sesuatu yang meyebar secara luas. Selain itu dalam berita ini juga terdapat sebuah gambar yang menampilkan Kabid Humas Polda Bengkulu Kombes Sudarno.

\section{Analisis pemberitaan kasus perundungan pada Tribunnews.com.}

Judul berita: Viral video bocah dibully berkali-kali dilempar ke sawah, pelaku diburu polisi

\section{Struktur sintaksis}

Penggunaan lead pada berita ini memaparkan mengenai adanya video viral yang memperlihatkan aksi perundungan yang dilakukan oleh sekelompok pemuda terhadap seorang bocah. Selanjutnya pada teks berita ini terdapat satu kutipan yang disampaikan oleh narasumber yaitu Kaporles Bogor AKBP Harun. Selain itu dalam berita ini terdapat penulisan opini wartawan yang terletak pada paragraf ketiga yang berisi pertanyaan apa maksud dibalis perlakuan tersebut. Kemudian pada penutup berisi pernyataan yang disampaikan oleh 
3151 Analisis Framing Berita Perundungan pada Media Online Detik.Com dan Tribunnews.Com sebagai Bahan Ajar Teks Berita di SMP - Neng Tika Harnia, Ferina Meliasanti, Hendra Setiawan

DOI: https://doi.org/10.31004/edukatif.v3i5.1240

Kaporles mengenai pengakuan pelaku yang melakukan hal tersebut hanya didasari oleh bercanda dan kini pelaku telah meminta maaf terhadap korban.

\section{Struktur skrip}

Penggunaan struktur skrip pada berita mengenai kasus penganiayaan terhadap perawat ini telah memenuhi semua unsur pembangun berita yakni unsur $5 \mathrm{~W}+1 \mathrm{H}$.

\section{Struktur tematik}

Dalam pemberitaan tersebut berisi 17 paragraf yang ditulis dengan baik sehingga berkesinambungan antar kalimat satu dengan yang lainnya. Selain itu dalam penggunaan unsur tematik wartawan tidak menggunakan kata ganti untuk nama untuk menyebutkan narasumber. Selanjutnya trdapat jenis koherensi penjelas yang ditandai dengan kata "dan" pada paragraf ke 6, 8, 11, 13, dan 17.

\section{Struktur retoris}

Terdapat penggunaan kata "bullying" pada judul yang berarti perbuatan yang dilakukan oleh pelaku terhadap korban hingga menyebabkan cedera, kerusakan fisik atau bahkan hilangnya nyawa seseorang. Selanjutnya terdapat kata penganiayaan dalam teks berita yang berarti perlakuan seseorang yang sewenangwenang berupa penyiksaan, penindasan dan sebagainya terhadap korban. Selain itu terdapat tampilan gambar yang memperlihatkan kondisi saat pelaku sedang menganiaya korban.

Judul berita: Video bullying siswa SMP Bengkulu viral di medsos, Polisi turun tangan

\section{Struktur sintaksis}

Penggunaan lead pada berita ini berisi pemaparan mengenai Polda Bengkulu yang menangani langsung ksus video bully bocah SMP yang viral di media sosial. kutipan sumber yang terdapat dalam berita ini berasal dari Kabid Humas Polda Bengkulu Sudarno. Selain itu dalam berita ini tidak mencantumkan sebuah opini dari wartawan. Kemudian penutup berita ini berisi pemaparan mengenai kronologis kasus bully dimana korban memberikan uang ongkos pulangnya kepada pelaku perundungan.

\section{Struktur skrip}

Penggunaan struktur skrip pada berita mengenai kasus penganiayaan terhadap perawat ini telah memenuhi semua unsur pembangun berita yakni unsur $5 \mathrm{~W}+1 \mathrm{H}$.

\section{Struktur tematik}

Pemberitaan mengenai kasus perundungan tersebut terdapat 14 paragraf yang ditulis dengan baik sehingga berkesinambungan antar kalimat satu dengan yang lainnya. Selain itu dalam penggunaan unsur tematik wartawan tidak menggunakan kata ganti nama untuk menyebutkan nama narasumber. Selanjutnya terdapat satu jenis koherensi penjelas yang ditandai dengan kata "dan" pada paragraf 4 dan 7 .

\section{Struktur retoris}

Terdapat penggunaan kata "bully" pada judul berita yang memiliki arti sebuah perbuatan yang dilakukan oleh pelaku terhadap korban yang menyebabkan cedera, kerusakan fisik atau matinya nyawa seseorang. Kemudian terdapat kata "viral" pada penulisan berita yang berarti sesuatu yang meyebar secara luas. Dan disertai gambar ilustrasi seorang siswa yang tengah dibully guna melengkapi teks pemberitaan tersebut.

Hasil analisis framing Zhongdang Pan dan Gerald M. Kosicki mengenai berita perundungan pada Detik.com dan Tribunnews.com dimanfaatkan sebagai bahan ajar pada pembelajaran materi teks berita di SMP kelas VIII. Materi ajar yang telah dirancang terlebih dahulu disesuaikan dengan kurikulum, RPP, dan silabus yang ditetapkan. Bahan ajar yang digunakan berupa handout yang berisi materi ajar yang disusun didasari hasil analisis framing berita perundungan pada Detik.com dan Tribunnews.com dengan menggunakan model analisis Zhongdang Pan dan Gerald M. Kosicki.

Dalam pembelajaran teks berita, fungsi framing digunakan untuk menganalisis unsur pada teks berita, selain itu dapat digunakan sebagai pengetahuan tambahan guna memahami isi dari suatu pemberitaan agar tidak termakan oleh berita hoaks. Tujuan dalam penyusunan bahan ajar handout guna memanfaatkan hasil 
3152 Analisis Framing Berita Perundungan pada Media Online Detik.Com dan Tribunnews.Com sebagai Bahan Ajar Teks Berita di SMP - Neng Tika Harnia, Ferina Meliasanti, Hendra Setiawan

DOI: https://doi.org/10.31004/edukatif.v3i5.1240

analisis framing teks berita dan agar lebih memudahkan siswa dalam proses pembelajaran terutama materi teks berita.

\section{KESIMPULAN}

Dapat disimpulkan bahwa pada Detik.com dan Tribunnews.com memiliki sebuah perbedaan dan persamaan dalam melakukan framing terhadap pemberitaannya mengenai kasus perundungan. Pada aspek sintaksis media Detik.com menuliskan pemberitaan dengan menggunakan ketenangan dimana dalam setiap judul pemberitaannya di framing dengan menggunakan pilihan kata-kata perdamaian. Sedangkan pada Tribunnews.com dalam menuliskan judulnya bersifat menggeretak dengan terdapat penggunaan kata "viral" dan melibatkan Polisi pada judul berta membuat masyarakat menjadi penasaran terhadap pemberitaannya. Unsur skrip pada kedua media ini telah mencapai kesempurnaan dimana keduanya telah menggunakan elemen $5 \mathrm{~W}+1 \mathrm{H}$ dalam menuliskan pemberitaannya dengan baik. Unsur tematik pada media Detik.com terdapat penggunaan kata ganti nama untuk menyebutkan narasumber dalam kutipan sumber dan terdapat koherensi penjelas dan sebab akibat dalam penulisan pemberitaannya. Sedangkan pada media online Tribunnews.com tidak menggunakan kata ganti dan hanya terdapat koherensi penjelas saja. Dan unusr retoris pada kedua media tersebut sama-sama menggunakan pilihan kata yang cukup sulit dipahami oleh masyarakat secara umum mengenai kasus perundungan dan penggunaan kata-kata yang menarik perhatian pembaca. selain itu disertai dengan tampilan gambar yang mendukung isi dari pemberitaan yang disampaikan. Bahan ajar yang dibuat yaitu berupa handout yang disusun sesuai antara materi ajar teks berita dengan Kompetensi Dasar silabus kelas VIII SMP. Handout dipilih dengan tujuan guna meningkatkan sebuah efektivitas pembelajaran sehingga siswa akan mudah dalam memahami materi teks berita.

\section{UCAPAN TERIMA KASIH}

Puji dan syukur saya panjatkan atas rahmat dan karunia Allah SWT, peneliti mengucapkan terima kasih kepada kedua orang tua yang senantiasa memberikan doa dan dukungan, dosen pembimbing I dan II, temanteman dan semua pihak yang membantu.

\section{DAFTAR PUSTAKA}

Ah. Januar As'ar. (2016). Analisis Framing Pemberitaan Pilkada Kaltim di Surat Kabar Kaltim Post dan Tribun Kaltim Edisi 11 Mei 2013. Jurnal Ilmu Komunikasi, 3(4), 200-214.

Armaiga Chandra. (2017). Konstruksi Berita Olahraga pada Media Massa Internet (Analisis Framing Berita Konflik Marquez dan Rossi Pada Sindonews.com. Jurnal Online Mahasiswa, 4(2), 1-15.

Ayu Nur Irwinesia Putri. (2012). Analisis Framingberita Demonstrasi Mahasiswa Semarang Terkait Kenaikan Harga Bbm pada Tv Borobudur. Jurnal The Messenger, 4(2), 19-26.

D Nilamsari, IA Ratnamulyani, M. L. (2016). Analisis Framing Pemberitaan Kota Bogor di Media Online Www.Heibogor.com Dan Www.Bogorplus.com. Jurnal Komunikato, 2(2), 107-113.

Eriyanto. (2018). Analisis Framing Konstruksi, Ideologi, dan Politik Media. Yogyakarta: Lkis Group.

Fikri Ali Kurnia, Shulfi Ana Helmi, S. D. R. (2021). Konstruksi Media Online Detik.com dan Kompas.com terhadap Vanuatu (Analisis Framing Pemberitaan Vanuatu Pasca Pengangkatan Isu Pelanggaran HAM Papua dalam Sidang Umum PBB ke-75). Jurnal Komunikasi Makna, 9(1), 29-38.

Hikmat, D. H. M. M. (2018). Jurnalistik Literary Journalism. Jakarta: Prenadamedia Group.

Ida safitri, Firman, N. (2019). Pengaruh Bahan Ajar Tematik Terpadu Terhadap Pencegahan Bullying di Sekolah Dasar. Jurnal Edukatf, 1(3), 244-249.

Kurniawan, D., \& Muktiyo, W. (2019). Framing Berita Presiden Donald Trump Oleh Media Asing dan Media Nasional. Jurnal Intelektiva, 1(3), 17-23. 
3153 Analisis Framing Berita Perundungan pada Media Online Detik.Com dan Tribunnews.Com sebagai Bahan Ajar Teks Berita di SMP - Neng Tika Harnia, Ferina Meliasanti, Hendra Setiawan DOI: https://doi.org/10.31004/edukatif.v3i5.1240

Maghfiroh, L. (2020). Analisis Framing Pemberitaan Kontroversi Film The Santri di Media Online VoaIslam.Com dan Tribunnews.Com. (Skripsi Sarjana, Universitas Agama Islam Negeri Purwekerto, 2020) Diakses dari http://repository.iainpurwokerto.ac.id/8173/

Rika Afiana, Wienike Dinar Pratiwi, E. N. (2021). Keefektifan Metode SQ3R dalam Pembelajaran Membaca Pemahaman Teks Fiksi di Masa Pandemi Covid-19 pada Siswa SMP. Jurnal Edukatf, 3(5), 2362-2370.

Rismayanti, R. (2020). Framing Berita Perundungan dalam Pemberitaan Media Elektronik sebagai Bahan Ajar Teks Berita untuk Siswa SMP (Analisis Framing Model Robert N. Entman). In Repository UPI. (Skripsi Sarjana, Universitas Pendidikan Indonesia, 2020) Diakses dari http://repository.upi.edu/53411/

Sejiwa. (2008). Bullying: Mengatasi kekerasan di sekolah dan lingkungan sekitar anak. Jakarta: PT Grasindo.

Sugiyono. (2017). Metode Penelitian Kuantitatif, Kualitatif dan R\&D. Bandung: PT Alfabet.

Suryawati, I. (2014). Jurnalistik Suatu Pengantar Teori dan Praktik. Bogor: Galia Indonesia.

Suryawati, Indah. (2011). Jurnalistik Suatu Pengantar Teori dan Praktik. Bogor: Ghalia Indonesia.

Umi Nurul Fadilah, Ahmad Murtafi Haris, Z. A. A. (2020). Framing Media Online Cnnindonesia.Com Dan Detik.Com Mengenai Kebijakan Transisi Di Dki Jakarta. Jurnal Ilmu Komunikasi, 3, 2.

Widarmanto, T. (2017). pengantar jurnalistik panduan awal penulis dan jurnalis. Yogyakarta: Araska. 